\title{
Why Alliances Entangle But Seldom Entrap States
}

\section{TongFi Kim}

This paper explains one of the central roles of alliance contracts, the prevention of undesirable military entanglement. The existing literature on alliances argues that entrapment is a major concern for potential and actual alliance partners, but it is difficult to point out clear cases of entrapment. I provide two answers to this puzzle: First, entrapment is a narrower concept than others have realized, and it is rarer than the literature suggests. Second, leaders anticipate entrapment and carefully design alliance agreements before and after states form alliances. I examine the second argument through case studies of U.S. alliance agreements with South Korea, Japan, and Spain.

For their helpful comments on earlier drafts of this article, the author is grateful to Bear Braumoeller, Brett Ashley Leeds, Autumn Lockwood Payton, Jeremy Pressman, Jennifer Dabbs Sciubba, Randall Schweller, Alexander Thompson, Naoto Tsuzaki, the editors and anonymous reviewers at Security Studies, as well as participants of the International Relations Research Workshop at the University of Maryland, College Park, February 9, 2009. 
Europe has a set of primary interests which to us have none; or a very remote relation...It is our true policy to steer clear of permanent alliances with any portion of the foreign world...it is unnecessary and would be unwise to extend them.

George Washington's farewell address, 1796

At first glance, Washington's message to the fledgling government seems to be a clear statement refusing alliance politics as part of foreign policy. His strong reluctance, however, underscores the importance of alliance contracts in international politics. If alliance contracts did not have real consequences, such a warning would not be warranted. In fact, within the same passages, Washington emphasizes the sanctity of contracts and argues that the existing "engagements be observed in their genuine sense," and he also allows for "temporary alliances for extraordinary emergencies."

In associating alliances and foreign entanglement, we must not miss that the contents of alliance contracts matter. To a certain extent, the mere formation of an alliance creates a vague and broad commitment that entangles the allies regardless of what is agreed. Conditions for activation of an alliance, however, are hardly trivial. Many alliances are not activated unless certain conditions are met, and advancements in recent literature make this point clear. Previously, the reliability of alliances had been considered to be as low as $27 \%$ or $23 \% .{ }^{1}$ For these earlier works, reliability meant whether states joined their alliance partners when wars occurred, regardless of the contents of the alliances. With the Alliance Treaty Obligations and Provisions (ATOP) dataset, which codes specific obligations of alliance agreements, Leeds, Long

\footnotetext{
${ }^{1}$ Alan Ned Sabrosky, "Interstate Alliances: Their Reliability and the Expansion of War," in The Correlates of War II: Testing Some Realpolitik Models, ed. J. David Singer (New York: Free Press, 1980), 161-98; and Randolph Siverson and Joel King, "Attributes of National Alliance Membership and War Participation, 1815-1965," American Journal of Political Science 24, no.1 (February 1980):1-15.
} 
and Mitchell find that alliances are indeed reliable $74.5 \%$ of the time. ${ }^{2}$ While the previous datasets coded inaction of allies as a violation of alliance agreements, many situations simply did not constitute a casus foederis, a situation in which the terms of an alliance are activated. The gap between these numbers suggests that the contents of alliances have important effects on their reliability (i.e. whether alliances are activated as expected), and consequently, on entanglement of the allies.

This paper explains one of the central roles of alliance contracts, the prevention of undesirable military entanglement. While alliances deter aggression, they are also considered to be a contagion mechanism for war expansion. ${ }^{3}$ The existing literature on alliances argues that entrapment - "being dragged into a conflict over an ally's interest that one does not share"-is a major concern for potential and actual alliance partners. ${ }^{4}$ There is, however, little accumulation of knowledge on the phenomenon of entrapment, and contractual aspects of alliances in the

\footnotetext{
${ }^{2}$ Brett Ashley Leeds, Andrew Long and Sara McLaughlin Mitchell, "Reevaluating Alliance Reliability: Specific Threats, Specific Promises," Journal of Conflict Resolution 44, no.5 (October 2000):686-99. For information on the ATOP dataset, see Brett Ashley Leeds, Jeffrey M. Ritter, Sara McLaughlin Mitchell, and Andrew G. Long, “Alliance Treaty Obligations and Provisions, 1815-1944," International Interactions 28, no.3 (2002): 237-260. Though with a smaller number of cases, an earlier study had also found a higher rate of reliability when conditions for alliance activation were met. See Ole Holsti, Terrence Hopmann and John Sullivan, Unity and Disintegration in International Alliances (New York: Wiley, John \& Sons, 1973).

${ }^{3}$ Randolph Siverson and Joel King, "Alliances and the Expansion of War." in To Augur Well: Early Warning Indicators in World Politics, eds. J. David Singer and Michael D. Wallace (Beverly Hills: Sage Publication, 1979), 37-49.

${ }^{4}$ Glenn Snyder, "The Security Dilemma in Alliance Politics,” World Politics 36, no.4 (July 1984): 467. On entrapment, also see Michael Mandelbaum, The Nuclear Revolution: International Politics before and after Hiroshima (New York: Cambridge University Press, 1981); Glenn Snyder, Alliance Politics (Ithaca: Cornell University Press, 1997); Victor Cha, Alignment Despite Antagonism : The United States-Korea-Japan Security Triangle (Stanford: Stanford University Press, 1999); and James Morrow, “Alliances: Why Write Them Down?" Annual Review of Political Science 3 (2000): 63-83. Another major risk in alliance politics is abandonmentdefection by an ally. On a trade-off between measures to correct the two problems, see Snyder, "Dilemma in Alliance" and Alliance Politics. "Chain-ganging" and "buck-passing" are similar concepts to entrapment and abandonment, respectively. See Kenneth Waltz, Theory of International Politics (New York: McGraw-Hill, 1979), 67, 165-69; and Thomas Christensen and Jack Snyder, "Chain Gangs and Passed Bucks: Predicting Alliance Patterns in Multipolarity," International Organization 44, no.2 (Spring 1990):137-68. Tierney suggests that defensive chain-ganging, where allies hold each other back from going to war, is possible. See Dominic Tierney, "Offensive and Defensive Chain-Ganging" (paper presented at the 49th Annual Meeting of the International Studies Association, San Francisco, 2008). Pressman explains that restraining another state and preventing war is a major reason for the formation and continuation of alliances. See Jeremy Pressman, Warring Friends: Alliance Restraint in International Politics (Ithaca: Cornell University Press, 2008).
} 
current literature are reduced to the issue of commitment as a solution to the danger of abandonment, a concept often coupled with entrapment. ${ }^{5}$

Theorists as well as policy makers talk about the danger of entrapment, but strangely, it is difficult to point out clear cases of entrapment. ${ }^{6}$ My explanation is two-fold: First, entrapment is a narrower concept than others have realized, and it is rarer than the literature suggests. Second, leaders anticipate entrapment and either do not form alliances when it would be a problem or demand escape clauses to minimize the problem, though only to the extent that they can afford to refrain from such alliances. Several conceptual problems have made entrapment difficult to even observe. Most problematically, alliance literature currently has at least two types of entrapment - what I call entanglement and entrapment - without establishing explicit analytical criteria for the phenomenon. I argue that the literature's use of the term "entrapment" is a mislabeling of the issue and that we need to distinguish among phenomena loosely explained by the term. The risk of entanglement (or entrapment broadly defined) is a necessary component of all military alliances, but states do not have to accept the risk of entrapment narrowly defined when entering alliances. My arguments and findings are intuitive, but they have important theoretical and policy implications on the issue of how states avoid undesirable military involvement in their allies' conflicts. By explaining how to observe entrapment analytically, this paper also illuminates the reason why entrapment is rare and yet not an illusory concept.

I will demonstrate that states carefully design alliance agreements before and after they

\footnotetext{
${ }^{5}$ Important progress has been made recently on the issue of abandonment. For explanations of when states tend to violate their alliance obligations, see Brett Ashley Leeds, "Alliance Reliability in Times of War: Explaining State Decisions to Violate Treaties," International Organization 57, no.4 (Fall 2003): 801-27; and Brett Ashley Leeds and Burcu Savun, "Terminating Alliances: Why do States Abrogate Agreements?" Journal of Politics 69, no.4, (November 2007):1118-32. Lai and Day analyze the relationship between moral hazard and designs of alliances, but I distinguish the issue of entrapment from moral hazard. See Brian Lai and Jonathan Day, "Reducing the Effects of Moral Hazard: Institutional Designs Within International Alliances" (paper presented at the 103rd Annual Meeting of the American Political Science Association, Chicago, 2007). I thank Alexander Thompson for suggesting me to consider the aspects of alliance contracts other than commitment.

${ }^{6}$ I thank Randall Schweller for pointing out the difficulty of finding the cases of entrapment.
} 
form alliances, and that is one of the reasons why serious military entrapment is rare. ${ }^{7}$ Alliance contracts reduce the risk of entrapment by specifying the nature of alliance obligations and conditions for their activation. This is not a new claim in the literature, but little empirical work has been done in its support. ${ }^{8}$ Indeed, 310 of 538 alliances in the ATOP dataset have one or more conditions for activation of the alliance obligations (e.g., specific adversary, specific location, non-provocation by the ally), and this paper explains when and how allies limit their alliance obligations. ${ }^{9}$ I argue that a state's alliance obligations are more likely to be conditional when it has more fear of entrapment or more bargaining power, and I test the argument with case studies of six alliance agreements.

The empirical section of this paper examines U.S. alliance agreements with the Republic of Korea (ROK), Japan, and Spain. These cases are ideal for my purpose, because they present variations in my explanatory variables, the fear of entrapment and intra-alliance bargaining power, and also because there are diplomatic records of the alliance negotiations, with which we can directly examine the variables rather than infer them from the circumstances. ${ }^{10}$ The U.S.ROK alliance is considered to be a typical case where a patron state fears entrapment by its client,

\footnotetext{
${ }^{7}$ Leaders will refrain from forming alliances when the risk of entrapment outweighs the expected benefits. The absence of a formal alliance tie between the United States and Taiwan after 1979 is a case in point, and leaders of NATO members probably became more reluctant to embrace Georgia's entry after the South Ossetia War in 2008. Another important reason for the rareness of entrapment is that the likely victims of military entrapment (i.e. suppliers of military protection) have a good chance of resisting entrapment exactly because they are more powerful than the lesser allies. For the "rational design" of various international institutions, see the special volume of International Organization on the subject (2001, vol.55, no.4).

${ }^{8}$ For example, see Morrow, "Why Write Them Down?": 73.

${ }^{9}$ I do not include "alliances" solely made of the obligation of nonaggression. Inclusion of these "alliances" would mean that pairs of countries such as the United States and Russia, and South and North Korea are allies. On the difference of nonaggression pacts from other alliances, see Michaela Mattes and Greg Vonnahme.. "Nonaggression Pacts are Different: Disaggregating the Alliance-Conflict Relationship" (paper presented at the 104th Annual Meeting of the American Political Science Association, Boston, 2008).

${ }^{10}$ My cases are six alliance agreements: U.S.-ROK(1953), U.S.-Japan (1951, 1960), U.S.-Spain $(1963,1970,1976)$. Using the different periods of the same alliances gives us a control for many factors. My case studies are structured and focused on the fear of entrapment and shifts in bargaining power. For a helpful guide to the case study method, see Alexander George and Andrew Bennett, Case Studies and Theory Development in the Social Sciences (Cambridge: MIT Press, 2004).
} 
but both conceptual and historical analyses suggest that the story is not so simple. The U.S.Japan alliance shows that military capabilities alone do not determine the fear of entrapment; in this case, it was the client state that feared entrapment. While Japan did not have enough bargaining power at the time of the 1951 treaty, it managed to insert safeguard clauses against entrapment in the revised security treaty of 1960. Among 26 American alliances in the ATOP dataset, the first period (1963-1970) of the alliance between the United States and Spain is the only one without a condition for activation. This, I argue, is due to the low level of commitments made and the low risk of entrapment for both sides. As concerns for entrapment increased, however, the bilateral agreement was revised to include clauses against entrapment.

In the sections that follow, I first explain problems with the concept of entrapment and argue that the label of entrapment should be more narrowly applied. I then argue that states design alliance agreements in such ways that they sometimes get entangled but seldom tricked into an undesirable conflict. The case studies of the United States' alliances with South Korea, Japan, and Spain demonstrate that concerns for entrapment and shifts in bargaining power affect the designs of alliances over time. In conclusion, I discuss the theoretical and real-world implications of this paper.

\section{CONCEPTUAL PROBLEMS OF "ENTRAPMENT”}

According to Michael Mandelbaum, who first coined the term "entrapment," every member of an alliance potentially fears that "he will be entrapped in a war he does not wish to fight." 11 Glenn Snyder, who popularized the concept, defines entrapment as "being dragged into a conflict over an ally's interests that one does not share, or shares only partially."12 Snyder's definition can accommodate nonmilitary entrapment, and it is argued that alliances can cause

\footnotetext{
${ }^{11}$ Mandalbaum, Nuclear Revolution, 151.

${ }^{12}$ Snyder, "Dilemma in Alliance," 467.
} 
political and economic entrapment as well. ${ }^{13}$ A broad interpretation of entrapment is useful when concerns for alliance politics have effects on policies in nonmilitary fields, but, for simplicity, I limit this paper to the discussion of military entrapment.

Unfortunately, the definitions listed above are too broad for the label of "entrapment," and the term is used to explain several distinct phenomena. ${ }^{14}$ For reasons discussed below, Mandelbaum and Snyder's "entrapment" should be called entanglement, of which entrapment is a subset. We need a more precise definition of entrapment that reflects the meaning of the word and differentiates different types of (non-neutral) third-party military involvement. In place of "entrapment" in a broad sense, I propose an alternative term, entanglement. I define entanglement as the process whereby a state is compelled to aid an ally in a costly and unprofitable enterprise because of the alliance. Entrapment is a form of undesirable entanglement in which the entangling state adopts a risky or offensive policy not specified in the alliance agreement. In order for states to benefit from alliances, they have to accept some risk of entanglement, because the benefits come from the possibility of entanglement. However, states can in fact benefit from alliances without accepting the risk of entrapment (i.e. being obligated to support their allies' offensive or risky behavior that draws them into undesirable situations). Let us briefly discuss three components of the definitions.

First, in order to play as central a role in alliance theory as it does now, entrapment must

\footnotetext{
${ }^{13}$ See, for example, Snyder, Alliance Politics, 357; and Galia Press-Barnathan, "Managing the Hegemon: NATO under Unipolarity” Security Studies 15, no.2 (April 2006): 280-281.

${ }^{14}$ Entrapment is sometimes erroneously equated with moral hazard even though the latter is neither a necessary nor a sufficient condition for the former. For example, see James Fearon, "Signaling Foreign Policy Interests: Tying Hands versus Sinking Costs," Journal of Conflict Resolution 41, no.1 (February 1997): 84; David Lake, Entangling Relations: American Foreign Policy in Its Century (Princeton: Princeton University Press, 1999), 53; Leeds, "Alliance Reliability": 806. What happens if an ally takes a risky policy and drags a state into a conflict, but the adventure was not caused by the expectation of support from the state? This is not moral hazard because the ally's recklessness is not due to the alliance tie, but it constitutes entrapment because the state gets involved in the conflict because of the alliance. The United States entrapped some of its allies into the Iraq War, but it waged the war regardless of their support.
} 
be observed as an independent effect of alliances. One of the most important questions to ask is, what would have happened if there were no alliance tie? If the answer to the counterfactual question does not differ much from the reality, the cause of the third-party involvement is not to be found in alliance politics. Naturally, the entrapped must be allied to the entrapping state, and the alliance must be an important cause of the military involvement. The United States, for example, was not entrapped into World War II or Korean War. When a third-party involves itself in a conflict for its own interests, aside from concerns for its alliance, the military involvement does not qualify as entanglement, let alone entrapment.

Second, entrapment should never be desirable in any form whereas entanglement in some cases can be desirable because the entangled state benefits from improved relationships with its ally. Glenn Snyder suggests that "the French military and some civilian leaders positively desired to be entrapped by a Russian adventure in the Balkans" before the First World War, because they were afraid of abandonment. ${ }^{15}$ Such a case is important because the positive desire derives from concerns for alliance politics, but we should call it a desire for entanglement.

Whereas a desire for entanglement is possible, a state cannot desire entrapment because the state is not "entrapped" into a conflict if it desires to be involved. A state usually has a choice in both entrapment and entanglement, but choosing to do something is different from desiring to do something. ${ }^{16}$ An entrapped state has to be reluctant for semantic reasons, while we also need to take into account the possibility that a state may actually desire entanglement in order to strengthen an alliance. When the desire for involvement in another state's conflict is not caused

\footnotetext{
${ }^{15}$ Snyder also notes that German military figures expressed a similar opinion "regarding the desirability of the war's breaking out over Austrian rather than German interests." See Snyder, Alliance Politics, 316-317.

${ }^{16}$ Even in cases of entrapment, where states are more reluctant than in other cases of entanglement, states must have made a choice to submit to the entrapment, unless their allies involved them in a conflict in irreversible ways (e.g. an ally launching an attack from the states' territories without their approval) or the enemy attacked them because of the alliance ties.
} 
by concerns for alliance politics, the involvement is not even entanglement.

Put differently, a state is not entrapped when the expected benefit of involvement exceeds the expected cost of involvement:

(i) A state desires to get involved in its ally's war when:

Expected benefit of involvement - Expected cost of involvement $>0$.

It is a desirable entanglement when the desire is attributable to benefits in alliance politics; there is no entanglement when the benefits derive from other factors. Even when the expected cost of involvement is higher than the expected benefit, a state can still choose to become entangled or entrapped, because there is a reputational cost for non-involvement. ${ }^{17}$

(ii) A state chooses to get involved in its ally's war when:

Expected benefit of involvement - Expected cost of involvement

$>0-$ Expected cost of non-involvement.

These two conditions should not be confused, and a third-party military involvement should not be called entrapment when condition (i) holds. Alliance agreements increase the cost of noninvolvement and make it rational for self-interested states to become entangled into undesirable situations.

Finally, entrapment is a subset of entanglement that is precipitated by offensive or risky behavior not agreed upon in advance. Neither Mandelbaum's nor Snyder's definition is explicit about this opportunistic element of entrapment, but the term "entrap" implies this, and the issue is crucial for both the theory and policy of alliance management. Unless alliance agreements

\footnotetext{
${ }^{17}$ Sometimes, "decision makers come to believe that support for one's allies, regardless of its consequences, is essential to their national prestige, and that the failure to provide support would ultimately result in their diplomatic isolation in a hostile and threatening world. This symbolic significance of an alliance commitment may also become linked with public opinion.... and the domestic security of elites, thus further increasing the importance of alliance solidarity." See Jack Levy, "Alliance Formation and War Behavior: An Analysis of the Great Powers, 1495-1975," Journal of Conflict Resolution 25, no.4 (December 1981): 582-583.
} 
specify what behavior is permissible, states will be tempted to abuse alliance agreements, and the fear of abuse can prevent otherwise beneficial alliances from forming. When states form alliances and negotiate the terms, therefore, they will try to minimize the risk of entrapment, a risk that is not essential to the expected functions of the alliances.

Because this paper is about how states cope with the risk of entrapment and how rare entrapment is, I do not discuss specific cases of entrapment. A couple of examples, however, illustrate my points. The Iraq War seems to be a case of entrapment for some states. The United States took an offensive policy, and some of its formal allies reluctantly joined the conflict because of the concerns for their alliances with the United States, although some may have gotten involved because of non-alliance concerns (e.g., the United Kingdom believing in the threat presented by Iraq), and some may have desired to join the conflict in exchange for various expected economic benefits. ${ }^{18}$ Japan and South Korea, for example, reluctantly sent troops to Iraq to avoid frictions with the United States; while these two countries also hoped that they would be rewarded in U.S. policy toward North Korea, they did not desire to get involved in the conflict. ${ }^{19}$ The military risk of the involvement for the U.S. allies was not significant, and this further supports my argument that states seldom get entrapped because they carefully adjust the risk. To a certain extent, states can choose the extent of entrapment; for instance, New Zealand was reluctantly involved in the American war in Vietnam due to its alliance with the United States, but it carefully limited its involvement. ${ }^{20}$

\footnotetext{
${ }^{18}$ On how the United States used economic linkage to form the coalition, see Randall Newnham, "“Coalition of the Bribed and Bullied?' U.S. Economic Linkage and the Iraq War Coalition,” International Studies Perspectives 9 , no. 2 (May 2008):183-200.

${ }^{19}$ Gerald Geunwook Lee, "South Korea's Faustian attitude: the Republic of Korea's Decision to Send Troops to Iraq Revisited." Cambridge Review of International Affairs 19, no.3 (September 2006): 481-493; and Phillip Saunders, "The United States and East Asia after Iraq." Survival 49, no.1 (March 2007): 141-152.

${ }^{20}$ Roberto Rabel. 2005. New Zealand and the Vietnam War: Politics and Diplomacy. Auckland: Auckland University Press. Australia was partially entrapped in the Vietnam War too, but its interest was more closely aligned with the United States because its leaders believed in the domino theory. See Ronald Frankum. 2001. The United
} 
In addition to being rare, entrapment is difficult to observe even when it actually happens. Because states try to avoid serious costs of entrapment, entrapment most likely occurs in situations where the involvement makes little difference. Victims of entrapment are more likely to be weaker allies with little power, because these states need alliances more desperately. Stronger states worry about entrapment, because they are larger suppliers of military force, but they typically also have stronger bargaining power to minimize the risk. Another reason why entrapment is inconspicuous is that real entrapment, unlike its ideal type, is likely to be partial. States are more likely to choose to be entrapped when the cost of entrapment is not truly dire or when their interests are partially served by the involvement. Consequently, even when entrapment happens, what we observe will be significantly different from the conventional image of entrapment in the literature.

Finally, let me briefly mention a case of non-entrapment, which might evoke the image of entrapment. World War I is a paradigmatic case of chain-ganging, a concept sometimes equated with entrapment, but no one really got entrapped into the war. ${ }^{21}$ Chain-ganging and buck-passing are often associated with alliance ties, but they are primarily processes of balancing and non-balancing, and balancing does not require formal alliance ties. The combatants of World War I — be they expansionist or defensive - joined the war to create a balance of power favorable to them and only partially to honor their alliance commitments. A state does not get "entrapped" into a conflict when its own interest is at stake.

\footnotetext{
States and Australia in Vietnam, 1954-1968. Lewiston, NY: Edwin Mellen Press; Jeff Doyle, Jeffrey Grey and Peter Pierce. 2002. Australia's Vietnam War. College Station, TX: Texas A\&M University Press.

${ }^{21}$ On chain-ganging in World War I, see Waltz, Theory of International Politics, 167; and Christensen and Snyder "Chain Gangs and Passed Bucks." Mandelbaum considered the outbreak of World War I to be a case of entrapment because "Britain, Germany, Russia, and France were drawn into war by the quarrels of their lesser allies," but he also conceded that the war is not "an unalloyed example of entrapment." See Mandelbaum, Nuclear Revolution, 152 and 260. On the absence of entrapment in World War I, also see Amanda Rosen, "Entrapped? Alliance Obligations and German Motivations in the Great War"(paper presented at the annual meeting of the Midwest Political Science Association, Chicago, 2006).
} 


\section{STATES AVOID ENTRAPMENT BY CONDITIONAL ACTIVATION OF ALLIANCE OBLIGATIONS}

With the conceptual problems understood, my argument is simple: the contents of alliance contracts are meant to prevent entrapment but not necessarily to prevent entanglement. After all, alliances are supposed to entangle allies, although deterrence does not require actual entanglement. Because the benefits of an alliance derive from the possibility of entanglement, preventing all entanglement is not an option if one wants to benefit from an alliance. Therefore, states carefully design alliance contracts so that they prevent entrapment while not diminishing the value of alliances by preventing entanglement altogether.

It is an intuitive argument but still an important one. States by definition desire to avoid entrapment, but that does not tell us whether states are able to avoid it or how they avoid it. I argue that states are usually successful in avoiding entrapment (hence, the lack of cases) and the contents of alliance contracts are important. Paul Schroeder once wrote that "analyzing and categorizing alliances according to their types or provisions (defensive or offensive, limited or unlimited, consultative or automatic, with or without military conventions, bilateral or multilateral) are not likely to be very helpful in describing what alliances really do," but types and provisions of alliances are in fact very important. ${ }^{22}$ My seemingly commonsense argument gives answers to some contestable issues; it suggests that contents of alliance agreement are important and avoiding entrapment is possible, in fact not too difficult, and it also leads to the explanation of specific ways states avoid entrapment.

From a rationalist perspective, two factors should significantly affect the designs of alliance agreements; (i) when a state has a strong fear of entrapment, it is more likely to have conditions on its alliance obligations; (ii) when a state has a strong bargaining power vis-à-vis its

\footnotetext{
${ }^{22}$ Paul Schroeder, "Alliances, 1815-1945: Weapons of Power and Tools of Management," in Historical Problems of National Security, ed. Klaus Knorr (Lawrence: University of Kansas Press, 1976), 255.
} 
ally, the state is more likely to have conditions on its alliance obligations. States fear entrapment because they cannot control their ally and yet might have to suffer the consequence of the ally's behavior. By imposing conditions on alliance obligations, states create escape clauses and limit their alliance commitment. Whereas the fear of entrapment explains motivations behind conditional alliance obligations, bargaining power of a state explains the capacity to impose the conditions; weaker states have to accept the risk of entrapment more often than stronger states. When states that do not have bargaining power have entrapment concerns, we will not necessarily witness entrapment, but we should see alliance agreements that involve a significant risk of entrapment for the states with weak bargaining power. For instance, Japan had very little bargaining power when it signed a security treaty with the United States in 1951, and the treaty entailed a significant risk of entrapment for Japan. Japan desperately needed the alliance, and the occupied country was in no position to refuse the agreement. When concerns for entrapment are extremely strong, alliances will no longer be attractive to the potential victims, and their bargaining power will strengthen. In such a case, an alliance will form only if the other state is willing to make some concessions to reduce the risk of entrapment.

The principal focus of this paper is on designs of alliance agreements, but the theoretical analysis should be applicable to cases where alliances did not form because of the dangers of entrapment. For instance, the United States did not formalize its alliance with Taiwan until December 1954, even though Taiwan clearly belonged to the Western bloc in the Cold War. As Chiang Kai-shek himself realized, "the U.S. was concerned...that the Chinese Nationalists would bring the U.S. into an effort to reconquer the mainland."23 During the negotiation process, Secretary of State John Foster Dulles made sure that the alliance was "on a basis which will not enable the Chinese Nationalists to involve" the United States "in a war with Communist

${ }^{23}$ Foreign Relations of the United States [FRUS] 1952-1954, vol.14, pt.1, 614. 
China." ${ }^{24}$ Similarly, although Israel has close links with the North Atlantic Treaty Organization, the fear of entrapment makes its admission into NATO difficult. ${ }^{25}$

In the following case studies, I examine how states design alliances to avoid the risk of entrapment, and how shifts in the fear of entrapment and bargaining power affect interactions between allies over time.

\section{CASE STUDIES}

The three alliances (and six agreements) examined below have significant variations in my explanatory variables, the fear of entrapment and intra-alliance bargaining power. When a state fears entrapment, it should demand safeguard clauses against the risk, and its alliance obligations should become more conditional. Similarly, when a state has strong bargaining power, it can impose more conditions on its alliance obligations. The following case studies directly demonstrate the causal effects of the explanatory variables by tracing the changing perceptions of the decision makers documented in diplomatic records and secondary sources.

\section{U.S.-ROK alliance}

Throughout most of its history, the U.S.-ROK alliance has been a stereotypical asymmetric alliance, where the patron state (the United States) fears entrapment, and its client state (Republic of Korea) fears abandonment. ${ }^{26}$ The alliance has also been considered a quintessential military alliance for aggregating power, because its function is clearly understood

\footnotetext{
${ }^{24}$ Ibid, 929.

${ }^{25}$ Josef Joffe, "Israel and NATO: A Good Idea Whose Time Will Never Come" (BESA Center Perspectives Papers No. 77, May 25, 2009).

${ }^{26}$ The situation changed in the mid 1990s, because South Korea realized the cost of reunification to be too high for the immediate future, and also because North Korea's nuclear development pushed the United States to a more active and aggressive stance toward the North Korean regime. Now, arguably, South Koreans have as many reasons to worry about entrapment as about abandonment. For South Korea's fear of abandonment and entrapment, see, for example, Kang Choi and Joon-Sung Park, "South Korea: Fears of Abandonment and Entrapment," in The Long Shadow: Nuclear Weapons and Security in 21st Century Asia, ed. Muthiah Alagappa (Stanford: Stanford University Press, 2008), 373-403; and Geun Lee, “The Nexus between Korea's Regional Security Options and Domestic Politics" (International Institutions and Global Governance Program, Japan Studies Program, Council on Foreign Relations, 2009).
} 
as deterrence and defense against the North Korean threat. When we examine the origin of the alliance, however, we find that there is more to it than that. America chose to formalize its defense cooperation with South Korea not simply because they were concerned about the regional balance of power. If that were the case, the alliance would have formed earlier, when an American occupation force was still in the southern half of the Korean Peninsula after the Second World War. Interestingly, the United States entered this alliance, because it did not want to be involved in the military conflict on the Korean Peninsula. When we look at the contents of the alliance, we understand why the United States was willing to continue the alliance; the alliance was designed in such a way that the United States actually faced little risk of entrapment. By accepting the risk of entanglement, the United States exercised control on its client state and minimized the risk of entrapment.

Ironically, the United States ended up allying with South Korea exactly because the former did not want to commit to the defense of the latter. The Mutual Defense Treaty between the United States and the Republic of Korea was signed on October 1, 1953, only a few months after an armistice was reached for the Korean War. The defense treaty was nothing inevitable, and unlike its alliances with Japan or Spain, the United States did not have strong strategic interests in forming the alliance. ${ }^{27}$ It was, however, this lack of interests that triggered the North Korean invasion, and subsequently, the formation of the military alliance. In January 1950, Secretary of State Dean Acheson, in his speech at the National Press Club, left Korea and Taiwan outside the U.S. defensive perimeter. Combined with the withdrawal of U.S. troops from the

\footnotetext{
${ }^{27}$ See, for example, Byung-joon Ahn, "The Origins and Evolution of the Korean-American Alliance: A Korean Perspective" (Asia Pacific Research Center, Stanford University, 1998); Koji Murata, "The Origins and Evolution of the Korean-American Alliance: A Japanese Perspective" (Asia Pacific Research Center, Stanford University, 1998); Nancy Bernkopf Tucker, "The Origins and Evolution of the Korean-American Alliance: An American Perspective" (Asia Pacific Research Center, Stanford University, 1998); Yong-Pyo Hong, State Security and Regime Security: President Syngman Rhee and the Insecurity Dilemma in South Korea, 1953-60 (New York: Palgrave MacMillan, 1999).
} 
Korean peninsula in 1949, it seemed to North Koreans that their invasion of the South would not be resisted by American force. Once the North Korean army crossed the $38^{\text {th }}$ parallel in June 1950, however, the United States changed its policy and fought a costly war for the next three years. The United States could not afford to lose the war because of its ramifications for other areas, but neither did it have strong motivations to keep fighting the costly war for the nationalistic ambitions of the South Korean president Syngman Rhee. President Rhee, on the other hand, did not want to stop the war until he united the country, no matter how devastating the fighting was for his country and the United States. Peace negotiations began as early as July 1951, but Rhee vehemently opposed a settlement and obstructed the process by doing such things as in 1953 unilaterally releasing North Korean prisoners of war, whose repatriation was a major issue for the communists. In the United States, Dwight Eisenhower came to power with a campaign promise to end the war, and he accepted Rhee's demand for a mutual defense treaty and military as well as economic aid in exchange for the latter's cooperation in the armistice. ${ }^{28}$ Thus, the United States had to fight a war because it did not want to commit to the defense of South Korea, and it ended up committing to the country's defense, because it wanted to stop the war.

Fully aware of the danger of entrapment by Rhee, the United States imposed conditions on its alliance obligations. Article 3 of the Mutual Security Treaty reads as follows:

Each Party recognizes that an armed attack in the Pacific area on either of the Parties in territories now under their respective administrative control, or hereafter recognized by one of the Parties as lawfully brought under the administrative control of the other, would be dangerous to its own peace and safety and declares that it would act to meet the common danger in accordance with its constitutional processes.

\footnotetext{
${ }^{28}$ FRUS, 1952-54, vol. 15, pt. 1, 1122-23; and John Woolley and Gerhard Peters, "President Dwight Eisenhower's Letter to President Syngman Rhee of Korea, Concerning Acceptance of the Panmunjom Armistice," The American Presidency Project [online]. (Santa Barbara: University of California), June 7th, 1953. Available from $<$ http://www.presidency.ucsb.edu/ws/?pid=9869> .
} 
By this clause, the United States limited its commitment to only the defense of South Korea, and it also avoided automatic involvement, unlike in alliances such as the North Atlantic Treaty Organization. ${ }^{29}$ Without leaving ambiguity, the United States clearly limited its defensive commitment to the status quo and avoided a situation where it had to defend the result of a revisionist move by South Korea. Furthermore, the alliance put the South Korean troops under the operational control of the U.S. commander in Korea, thereby directly controlling the client state's military action. ${ }^{30}$ Granted, by forming an alliance, the United States incurred the risk of entanglement or entrapment, but this also led to a reduced risk of military involvement on the Korean Peninsula because the alliance improved deterrence against North Korea and imposed a control on risky behavior by South Korea. Thus, the U.S.-ROK alliance was not simply a "weapon of power" but also a "tool of management and control,"31 and the United States provided South Korea with security in exchange for its control on the latter's autonomy. ${ }^{32}$ The control has arguably been quite effective, considering that South Koreans have not been allowed to retaliate for various small-scale operations by North Korean special forces. ${ }^{33}$ With respect to

\footnotetext{
${ }^{29}$ The U.S. alliance with Taiwan had similar clauses, whereas the Australia, New Zealand, United States Security (ANZUS) Treaty and the U.S. alliance with the Philippines did not include them. See Astri Suhrke, "Gratuity or Tyranny: The Korean Alliances," World Politics 25, no.4 (July 1973): 518. Clearly, this is due to the risk of entrapment by Chiang Kai-shek's Taiwan. In its alliance with the Republic of China, the United States limited its defensive commitment to Taiwan and the Pescadores. Victor Cha argues that the "United States created a series of bilateral alliances in East Asia" partly "to constrain anticommunist allies in the region that might engage in aggressive behavior against adversaries that could entrap the United States in an unwanted larger war." See Victor Cha, "Powerplay: Origins of the U.S. Alliance System in Asia." International Security 34, no.3 (Winter 2010): 158 ${ }^{30}$ Peacetime control of South Korean troops was transferred back to the country in 1994. The Pentagon proposed that the wartime command be returned in 2009, but the transfer was put off until 2015 at the request of the South Korean government.

${ }^{31}$ Schroeder, "Weapons of Power and Tools of Management." This point more directly applies to the U.S. motivation to form alliances with Japan and West Germany. This paper illustrates specific means with which states control their allies, and it demonstrates that types and provisions of alliances matter, contrary to Schroeder, 255. For an extension of Schroeder's argument, see Patricia Weitsman, Dangerous Alliances: Proponents of Peace, Weapons of War (Stanford: Stanford University Press, 2004).

32 James Morrow, "Alliances and Asymmetry: An Alternative to the Capability Aggregation Model of Alliances," American Journal of Political Science 35, no.4 (November 1991):904-33.

${ }^{33}$ See, for example, Don Oberdorfer, The Two Koreas: A Contemporary History (Revised and Updated Edition),
} 
the cost of possible entanglement or entrapment, the treaty does not make the United States do much more than it would do without a formal alliance. The United States was not allied with the newly-born South Korean state, but it intervened in the Korean War anyway. Since the United States could not afford to ignore a renewed offensive by the communist bloc, regardless of its formal tie with South Korea, it actually bore very little additional risk by forming an alliance with the Republic of Korea.

Although there have been changes in the U.S.-ROK security cooperation (e.g., revisions of the Status of Forces Agreement, creation of the Combined Forces Command), the basics of the alliance have not changed after more than 50 years. There are legal and strategic explanations for this. The technical side of the story is that there is no institutional setting for renegotiation; the alliance has an indefinite duration with a requirement of a one-year advance notice for termination. Syngman Rhee wanted the alliance to be effective for an indefinite time, and the United States accepted his demand after adding the termination clause. Rhee insisted that South Korea should be treated like Japan in the 1951 U.S.-Japan security treaty, which also had no arrangement for renegotiation. ${ }^{34}$ As we will see, the 1951 treaty was actually an unequal treaty favoring the United States, but Rhee did not understand the difference between benefits provided by the legal obligations on one hand and benefits Japan obtained due to its strategic importance to the United States on the other hand. Of course, if South Korea or the United States had a strong desire to change the status of their relationships, the lack of renegotiation arrangement would not have stopped them from changing the nature of the alliance. Strategic situations, however, did not push the allies toward renegotiation. South Korea was too dependent on the

\footnotetext{
(New York: Basic Books, 2002).

${ }^{34}$ Robert T Oliver, Syngman Rhee and American Involvement in Korea, 1942-1960: A Personal Narrative (Seoul: Panmun Book Co, 1978); Oknim Chung, "The Origins and Evolution of the Japanese-American Alliance: A Korean Perspective" (Asia Pacific Research Center, Stanford University, 1998); and Tucker, "An American Perspective.”
} 
United States to demand renegotiation, because it faced a very specific and clear threat to the north, which was not the case for Japan or Spain. Meanwhile, as explained above, the costbenefit calculation of the alliance favored the status quo for the United States too, although troop reductions of the U.S. Forces in Korea at times became serious issues for the allies. In addition, policy-makers of both the United States and the Republic of Korea were very cautious about modifying the alliance, because the uncertainty of possible North Korean reactions posed a serious military risk to them. There was more room for change in the U.S. alliances with Japan and Spain because the allies faced much lower military risks, and also because Japan and Spain had something the United States desired.

Because the United States had both more fear of entrapment and stronger bargaining power than South Korea, the United States naturally made its alliance obligations conditional. Controlling aspects of alliances are often downplayed in the public discourse for political reasons, but the case shows that they are no less important than capability aggregation aspects of alliances. In the future, if South Korea's fear of entrapment or bargaining power increases, the design of the alliance will be reconsidered. ${ }^{35}$

\section{U.S.-Japan alliance ${ }^{36}$}

In contrast to South Korea's relationships with the United States, it was Japan that feared

\footnotetext{
${ }^{35}$ In 2005, then-President Roh Moo-hyun said that "our citizens will not become embroiled in Northeast Asian conflicts without our consent" at the graduation ceremony of the Air Force Academy's 53rd class. Jeong-rok Shin, "Roh Says No to Greater USFK Role in Northeast Asia," Chosun Ilbo, March 8, 2005. http://english.chosun.com/w21data/html/news/200503/200503080028.html. During the Roh administration, South Korean government unsuccessfully tried to make it mandatory for the United States to get prior consent when moving United States Forces Korea (USFK) elsewhere.

${ }^{36}$ In addition to the works cited below, see John Welfield, Empire in Eclipse: Japan in the Postwar American Alliance System (London: Athlone Press, 1988); Roger Buckley, US-Japan Alliance Diplomacy, $1945-1990$ (New York: Cambridge University Press, 1992); and Hidetoshi Sotooka, Masaru Honda and Toshiaki Miura, 2001. Nichibei Domei Hanseiki: Anpo to Mitsuyaku [Half Century of the Japan-U.S. Alliance: Security Treaty and Secret Promises] (Tokyo: Asahi Shinbunsha, 2001).
} 
military entanglement in the U.S.-Japan alliance. ${ }^{37}$ While a stronger ally tends to fear military entrapment because it supplies military force for an alliance, the weaker fears entrapment because it has little control over its ally and still faces the consequences of the ally's actions. American military bases and the alliance brought Japan a risk of entanglement or entrapment into the American struggle against communism. Meanwhile, the risk of entrapment for the United States was very low, because Japan was not likely to take any offensive or independent military policy, and the cost of possible entanglement was also low, because the United States, allied to Japan or not, could not afford to lose Japan to the communist bloc. ${ }^{38}$ Although Article 9 of the Japanese constitution, which was originally imposed by the United States, has been a powerful shield against entanglement, the pacifist constitution also increased Japanese sensitivity to the risk of entanglement. Therefore, Japanese leaders did not miss their opportunity to reduce the risk of entanglement at the revision of the U.S.-Japan alliance in 1960.

\section{1 security treaty between the United States and Japan}

Deploring the inequities of the 1951 treaty, Nobusuke Kishi said that "In this way, [Japan is] like a Manchukuo." ${ }^{39}$ Like Kishi, who led the revision of the treaty as prime minister (19571960), many Japanese considered the treaty to be unequal. While the treaty granted the United States the right to deploy its forces "in and about Japan," these forces were not committed to the defense of Japan. ${ }^{40}$ Moreover, because there was no institutional arrangement for consultation,

\footnotetext{
${ }^{37}$ Because the postwar Japan has been extremely pacifist, it has tried to avoid military entanglement in a very broad sense, and not just military entrapment as I defined earlier.

${ }^{38}$ In George Kennan's words, Japan was one of the "areas of the world...we cannot permit...to fall into hands hostile to us," and one of the "five centers of industrial and military power in the world which are important to us from the standpoint of national security." Quoted in John Lewis Gaddis, Strategies of Containment: A Critical Appraisal of American National Security Policy During the Cold War (New York: Oxford University Press, 2005), 29.

${ }^{39}$ Akihiko Tanaka, "The Domestic Context of the Alliance: The Politics of Tokyo" (Asia Pacific Research Center, Stanford University, 2000), 18. Manchukuo is Japan's puppet state in China, established in 1932 and dissolved as Japan lost the Pacific War.

${ }^{40}$ Article I of the treaty says: "Such forces may be utilized to contribute to the maintenance of international peace and security in the Far East and to the security of Japan." As Japanese leaders comforted themselves, however, it
} 
Japan did not have a formal procedure by which to voice its opinion on the management of the alliance, let alone to control American behavior. Thus, the treaty imposed a significant risk of entanglement on Japan but not on the United States, at least in terms of legal obligations. In practice, Japan benefited politically, economically and militarily from its alliance with the United States, and the unequal security treaty can also be considered to be a quid pro quo for the favorable peace treaty, which ended the American occupation of Japan. ${ }^{41}$ Nevertheless, it cannot be denied that the text of the treaty was unfavorable to Japan. In addition to the lack of defense commitment, the treaty permitted Americans to intervene in domestic disturbances of Japan, prohibited Japan from granting military and base-related rights to any third power without the prior consent of the United States, and did not allow either party to terminate the alliance.

Japan's initial efforts to revise the treaty were unsuccessful, reflecting the country's weak international standing at the time. Foreign Minister Mamoru Shigemitsu of the Hatoyama administration visited the United States in 1955 with a proposal to revise the treaty, but his request was instantly rejected. ${ }^{42}$ As Secretary of State John Foster Dulles noted, replacement of the 1951 treaty "could not be done without a grave loss of advantage to the United States," and Americans were not going to change the advantageous arrangement "unless pressure in Japan for a new treaty became a great deal stronger." ${ }^{43}$ Meanwhile, the Japanese fear of entanglement was heightened by such events as the Soviet launching of Sputnik in 1957 and the Quemoy crisis in

\footnotetext{
could be argued that the stationing of the American troops meant de facto commitment to the defense of Japan.

${ }^{41}$ Kazuya Sakamoto, Nichibei domei no kizuna: Anpo-Joyaku to sogosei no mosaku [The Japan-U.S. Alliance Nexus: The Security Treaty and the Search for Mutuality] (Tokyo: Yuhikaku, 2000), 62. When Americans considered the peace treaty, they wanted "the right to maintain armed forces in Japan, wherever, for so long, and to such extent as it deems necessary," and the security treaty coupled with the peace treaty provided them with a solution to the problem (FRUS, 1950. vol.6, 1294).

${ }^{42}$ To a certain extent, the failure was attributable to the negotiation tactic Shigemitsu used with Secretary of State John Foster Dulles. Kishi, who accompanied Shigemitsu, did not fail to learn the lesson. See Sakamoto, Japan-U.S. Alliance Nexus, 164-170).

${ }^{43}$ FRUS, 1955-1957, Volume 23, part 1, 42.
} 
the Taiwan Strait in $1958 .{ }^{44}$ The fear in turn made the Japanese public increasingly critical of U.S. bases. Japanese dependence on the United States also seemed to be declining because of Japan's diplomatic normalization with the Soviet Union and its accession to the United Nations in $1956 .^{45}$

\section{Revision of the alliance in 1960}

Although Japan's postwar recovery and its improved position in international society could explain its increased voice in the alliance at a very general level, two other factors are crucial in explaining the revision of the treaty. First, the United States perceived increased pressure for change from the Japanese public. By January 1958, Dulles recognized that the American posture in Japan and Okinawa could not continue safely: "If we try merely to sit on our treaty rights," Dulles remarked, "we shall end by being blown out by popular sentiment, spearheaded by a Japanese government of hostile and neutralist, if not pro-Communist, sentiment."46 Douglas MacArthur II, U.S. Ambassador to Japan (1957-1961), understood the grievances of the Japanese and repeatedly recommended the revision of the treaty as an American initiative: "there is a universal desire among the Japanese to liberate themselves from those terms of the security relationship with the United States which they consider as being 'genuinely unequal,"” and "[t]here is, as we all recognize, actual inequality." time when the Japan Socialist Party still presented a serious threat to the rule of factious conservative politicians, and the socialists attracted considerable support from the public by criticizing Japan's military association with the United States.

\footnotetext{
${ }^{44}$ Tetsuya Kataoka and Ramon Myers, Defending an Economic Superpower: Reassessing the U.S.-Japan Security Alliance (Boulder: Westview Press, 1989), 18; and Masashi Nishihara and Jitsuo Tsuchiyama eds. Nichibei Doumei $Q \& A 100$ [The Japan-U.S. Alliance $Q \&$ A 100] (Tokyo: Aki Shobou, 1998), 183.

${ }^{45}$ See Sakamoto, Japan-U.S. Alliance Nexus, 191.

${ }^{46}$ Dulles's statement is quoted in "Memorandum of Howe to Robertson" January 24, 1958, Lot File 61 D 68, RG 59, Stack 250, Row 49, Compartment 19, Shelf 6, E-1341, Subject Files Relating to Japan, 1957-59. Box 12, National Archives at College Park.

${ }^{47}$ FRUS, 1958-1960, vol.18, 25.
} 
Second, in such a difficult time for U.S.-Japan relations, Kishi's ascendance to power presented an attractive opportunity for Americans to consolidate the alliance. Despite his nationalistic ideology and three years of imprisonment as a class-A war criminal, Kishi quickly became a favorite politician of the United States after he was released. ${ }^{48}$ Working with U.S. Ambassador John Allison, Kishi strengthened his credentials as a strong pro-U.S. political leader by unifying divided conservative politicians, which resulted in the creation of the Liberal Democratic Party in 1955. MacArthur II, who replaced Allison as the ambassador, also viewed Kishi as the best Japanese leader to work with for consolidating the U.S.-Japan relationship. Therefore, before Kishi's visit to Washington in June 1957, Dulles reported to President Eisenhower that Kishi "gives every indication of being the strongest Government leader to emerge in postwar Japan," and that "the time has come to take the initiative in proposing a readjustment of our relations with Japan." 49

Americans made a spontaneous move toward the revision of the treaty once they recognized the necessity. The U.S. and Japanese governments announced on September 11, 1958 that they would begin negotiating a new agreement, and they signed the new treaty on January 19, 1960. Many provisions of the old treaty unpopular with the Japanese were revised, and three points are particularly important in ameliorating Japan's fear of entanglement. First, Article 5 of the 1960 treaty states that "Each Party recognizes that an armed attack against either Party in the territories under the administration of Japan would be dangerous to its own peace and safety and declares that it would act to meet the common danger in accordance with its constitutional provisions and processes" (emphasis added by the present author). The emphasized part in the original American proposal read "in the Pacific," but the Japanese

\footnotetext{
${ }^{48}$ Michael Schaller, "America's Favorite War Criminal: Kishi Nobusuke and the Transformation of U.S.-Japan Relations,” Working Paper 11. Japan Policy Research Institute. July 1995.

${ }^{49}$ FRUS, 1955-1957, vol. 23, part 1, 346-348.
} 
minimized the risk of entanglement by successfully restricting the commitment to its own territory and by excluding even the Ryukyu (Okinawa) and Bonin (Ogasawara) islands, which were administered by the United States at the time. ${ }^{50}$ The Japanese also succeeded in emphasizing the restrictions imposed on their military policy by its "constitutional provisions and processes." Second, in exchanged notes on the implementation of the 1960 treaty, the Japanese imposed an obligation of prior consultation on the introduction of U.S. nuclear forces and on the use of U.S. bases in Japan for military combat operations other than those conducted under Article 5. Although there are loopholes and secret provisions that cast doubt on the effectiveness of the prior consultation, ${ }^{51}$ the Japanese did put a limit on the use of U.S. facilities in Japan. ${ }^{52}$ Third, Article 10 stipulated that "after the Treaty has been in force for ten years, either Party may give notice to the other Party of its intention to terminate the Treaty, in which case the Treaty shall terminate one year after such notice has been given.” Although it was highly unlikely that either party would use this provision, it still gave each a legal exit from the alliance, which would limit the risk of entanglement. The Japanese probably requested the limit of duration to give the treaty an appearance of equality, but the Spanish case suggests that an alliance partner could gain considerable leverage from such a limit on the duration of an alliance.

I do not delve into domestic politics of the treaty revision, but there is a strong irony about Kishi's leadership in this episode. ${ }^{53}$ Despite many improvements from the 1951 treaty,

\footnotetext{
${ }^{50}$ Sakamoto, Japan-U.S. Alliance Nexus, 237-247.

${ }^{51}$ For example, two sides secretly agreed that they would forgo prior consultations in the event of attack against South Korea. See Yoshitaka Sasaki, "Secrecy undermines Japan-U.S. defense partnership," Annual Reports 2000, Asahi Shimbun, Available from <http://www.asahi.com/english/asianet/report/eng 2000_16.html $>$.

${ }^{52}$ Sakamoto, Japan-U.S. Alliance Nexus, 252-266.

${ }^{53}$ See, for example, Yoshihisa Hara, Nichi-Bei kankei no kozu: Ampo Kaitei o kensho suru [The design of the United States-Japan relationship: An examination of the Security Treaty Revision of 1960]. (Tokyo: Nihon Hoso Shuppan Kyokai, 1991); Michael Schaller, Altered States: The United States and Japan Since the Occupation (New

York: Oxford University Press, 1997); and Nicholas Evan Sarantakes, "Alliance in Doubt: American Reaction to the 1960 US- Japanese Security Treaty Crisis," American Diplomacy 4, no.4 (Autumn 1999), $<$ http://www.unc.edu/depts/diplomat/AD_Issues/amdipl_13/sarantakes1.html $>$.
} 
Kishi's political style and image made the Japanese public suspicious of the 1960 treaty and triggered what is probably the largest political disturbance in postwar Japan. President Eisenhower's trip to Japan was canceled for security reasons, and Kishi was forced to resign. It is also interesting that Kishi's opponents in the Liberal Democratic Party (not just the Socialists) used the fear of entanglement to stall the agreement, which would consolidate Kishi's power in the LDP.

The case of the U.S.-Japan alliance clearly demonstrates that a weaker ally can fear entrapment and that bargaining power plays an important role in designs of alliance agreements. Japan feared entrapment but was able to insert safeguard clauses in the alliance treaty only after its bargaining position improved. As noted above, Japan tried to avoid not only entrapment but entanglement in a very broad sense. The pacifism of postwar Japan partially explains the policy, but Japan could afford to take such a policy, because it had little fear of abandonment. When Japan felt less indispensable to the United States, for example, after the Sino-U.S. rapprochement or the end of the Cold War, Japan increased its commitment to the alliance and became more willing to accept the risk of entanglement. ${ }^{54}$

\section{U.S.-Spain alliance}

The U.S.-Spain alliance, especially in its early period, was relaxed about the risk of entrapment or entanglement. This was natural, because the alliance presented a very small risk of entrapment or entanglement to its members. ${ }^{55}$ Strategically, the two countries faced no major military threat around Spain, and neither did they have revisionist goals that could entrap the

\footnotetext{
${ }^{54}$ The two governments approved the first Guidelines for U.S.-Japan Defense Cooperation in 1978, and Japan began sending its troops abroad in the 1990s.

${ }^{55}$ Entanglement was unlikely, and if it happened in the context of East-West confrontation, it would not have been costly, because the two countries would not have been able to avoid fighting regardless of the alliance.
} 
other side. ${ }^{56}$ The frontline of the European Cold War was far away, and neither party desperately needed the other's help for countering external military threats. Franco sought economic and political goals in the military arrangement with the United States, and "the value of the Spanish bases" to the United States was, according to a classic study on the subject, "prospective and relative rather than immediate and absolute. ${ }^{, 57}$ Consequently, the alliance committed the two states very little in terms of military obligations - too little to entangle them into military conflicts. This, I argue, is the reason why the first period of the U.S.-Spain alliance is the only American alliance agreement that has no condition in the ATOP dataset.

In fact, the low level of commitment makes the status of the military arrangement somewhat ambiguous. We can find the origin of the alliance in the Pact of Madrid, which was signed in 1953 as a quid pro quo arrangement that provided aid to Spain for U.S. bases there. Arthur Preston Whitaker observed that the pact did "not constitute a full-fledged military alliance" but rather "a quasi-alliance." ${ }^{, 58}$ The ATOP dataset codes the bilateral relationship as a military alliance from 1963, when the base agreement was extended and the two sides jointly declared that a "threat to either country, and to the joint facilities that each provides for the common defense, would be a matter of common concern to both countries, and each country would take such action as it may consider appropriate within the framework of its constitutional processes." Although the Spanish tried to present the series of base agreements as full partnerships, they knew the reality and continued to seek a more formalized alliance. ${ }^{59}$ Until the third period of the alliance (1976-1981), the United States never gave Spain a security

\footnotetext{
${ }^{56}$ Threats to Spanish colonies in North Africa intensified later but were nothing comparable to those faced by American allies elsewhere. With respect to the risk from irredentism, Franco would not try to regain Gibraltar by force, unlike Syngman Rhee or Chiang Kai-shek.

${ }^{57}$ Preston Whitaker, Spain and Defense of the West; Ally and Liability (New York: Harper, 1961), 65.

${ }^{58}$ Ibid, 45.

${ }^{59}$ A Spanish diplomatic record on the base negotiation states that "[ $\left.\mathrm{t}\right]$ he United States is not proposing to Spain a marriage but a concubinage." See Rodrigo Botero, Ambivalent Embrace: America's Troubled Relations with Spain from the Revolutionary War to the Cold War (West Port: Greenwood Press, 2001), 162.
} 
guarantee. ${ }^{60}$ While the Spanish Cortes (legislature) approved the base agreements as treaties, the United States treated them as executive agreements until 1976. The United States valued its bases in Spain but had little more interest in its relationship with Spain. Many in Western Europe and the United States (and anti-Franco elements in Spain) opposed the bilateral relationship because of Franco, and the American negotiators could reasonably argue that securing the ratification of the military pact in the Senate was unfeasible. As time passed, however, the two states' military cooperation gradually became formalized. Consistent with my argument, the two countries added safeguards against entrapment in the process of consolidating the alliance. ${ }^{61}$

In addition to being formed by an executive agreement rather than a treaty, the U.S.Spain alliance is different from the Korean and Japanese cases in its frequent renewals. The Spaniards were wise in limiting the duration of the base agreements (five years after the first ten years), because the renewals gave them opportunities to improve their position in the bilateral relationship and also because the time limit gave them leverage in base negotiations. ${ }^{62}$ At the time of the Pact of Madrid in 1953, Spain was isolated from the rest of the world as a pariah state under the rule of the "last Fascist dictator," and its "greatest single gain consisted in the mere fact

\footnotetext{
${ }^{60}$ Even for the 1976 treaty, the U.S. government was reluctant to admit that it constituted a security guarantee. See Richard Rubottom and Carter Murphy, Spain and the United States: since World War II (New York: Praeger, 1984), 115-119. Spain joined North Atlantic Treaty Organization (NATO) in 1981.

${ }^{61}$ Although I focus on how the United States and Spain adjusted their alliance in order to reduce the risk of entrapment, the risk of entrapment or entanglement was relatively low and continued to be a minor issue in this alliance. The main concern of the Spanish negotiators was the financial compensation for U.S. bases, and not security matters. See Angel Viñas, "Negotiating the U.S.-Spanish Agreements, 1953-1988: A Spanish Perspective," Jean Monnet/Robert Schuman Paper Series 3, no. 7 (September 2003). Meanwhile, Americans did not have to worry about entanglement because they were careful not to give any security guarantee to the Spanish in the first place.

${ }^{62}$ For a theory of optimal duration and renegotiation provisions that considers changes in bargaining power, see Barbara Koremenos, "Can Cooperation Survive Changes in Bargaining Power? The Case of Coffee," Journal of Legal Studies 31, no.1, (January 2002):259-83. The Spanish case may be rather special because the Spaniards could reasonably expect increased bargaining power in the future once their tie with the United States breaks the country's political isolation. States sometimes use incomplete contracts when they expect their bargaining position to improve after renegotiations. See Alexander Cooley and Hendrik Spruyt, Contracting States: Sovereign Transfers in International Relations (Princeton: Princeton University Press, 2009), 9-10.
} 
that the agreement had been signed." ${ }^{\circ 3}$ Spain demanded more as its international standing became normalized, and base negotiations presented an excellent stage for the adjustment. Another benefit from the limited duration comes from the nature of military bases; once constructed, they become a natural part of the basing-state's strategy and costly to lose. Although the Spanish themselves were not going to sever their ties with Americans, American records on the base negotiations indicate that the time limit on base agreements gave the Spanish a strong bargaining chip. ${ }^{64}$ Spain won the 1963 joint declaration, largely because the United States needed to renew the base agreements, and every major change in the U.S.-Spain alliance occurred when base agreements were about to expire.

\section{U.S.-Spain alliance before 1970}

Because the alliance was essentially a military base agreement for a long time, the most important provisions of the alliance concern the use of the bases. ${ }^{65}$ Until 1970, Americans had a free hand in their use of the bases in Spain. ${ }^{66}$ As American records indicate, "Spain has allowed" the United States "to use these bases for practically any purpose the U.S. deemed necessary."67 Despite (or exactly because of) the paramount importance of the issue, the United States proposed and Spain accepted making the wartime activation clause a secret and technical note to the base agreement. The note allowed the United States to use the bases in case of evident Communist "aggression" or in other cases that threaten the "security of the West" but did not specify what these words meant. In reality, Americans were allowed to use the bases whenever

\footnotetext{
${ }^{63}$ Whitaker, Spain and Defense of the West, 43.

${ }^{64}$ On the other hand, Franco's dependence on the United States placed Spain in a disadvantageous position in these negotiations. See Viñas, "Negotiating the U.S.-Spanish Agreements."

${ }^{65}$ On the patterns of base negotiations between the United States and Spain, see Daniel Druckman, "Stages, Turning Points, and Crises: Negotiating Military Base Rights, Spain and the United States," Journal of Conflict Resolution 30, no.2 (June 1986): 327-360; and Daniel Druckman, "Negotiating Military Base-Rights with Spain, The Philippines, and Greece: Lessons Learned" (Center for Conflict Analysis and Resolution. Occasional Paper 2, 1990), http://icar.gmu.edu/op 2 druckman.pdf

${ }^{66}$ Viñas, "Negotiating the U.S.-Spanish Agreements."

${ }^{67}$ FRUS, 1961-1963, vol.13, 1018.
} 
they liked and only had to inform the Spanish about their intentions. The Spanish gave authorizations to activate the bases in such cases as the 1958 Lebanon crisis and the U.S. evacuations from Congo in 1964 and Libya in 1969, all of which were hardly related to Communism or threats to the security of the West. Still, in other cases such as the Cuban missile crisis, the United States failed to inform Spain about the activation of the bases. ${ }^{68}$ Understandably, many Spaniards voiced their concern about the risk of entrapment, but it is not clear how serious Spanish leaders perceived the risk to be, because Spanish negotiators usually mentioned the risk of entrapment as a tactic to raise the price on the bases.

\section{Agreement of Friendship and Cooperation between the United States and Spain}

The negotiations for the 1970 agreement revolved around such topics as Spanish entry into NATO, an American security guarantee, and the amount of aid to Spain, but for the present purpose, I will focus on the limit imposed on American use of the bases in Spain.

Before the 1970 renewal, several events made the Spaniards more critical of American bases. In 1966, for example, an American bomber collided with a refueling plane and dropped four hydrogen bombs on the land and in the sea near the small Spanish village of Palomares. Diplomatically, the 1967 war in the Middle East made Spain realize that its pro-Arab policy was compromised by American use of the Spanish bases for such contingencies. ${ }^{69}$ In addition, the Spanish bargaining power was perceived to be rising because of increased Soviet presence in the Mediterranean and America's loss of Wheelus Air Base in Libya subsequent to Qaddafi's coup in $1969 .^{70}$ A memorandum for the National Security Council Review Group summarizes the political concerns of the Spanish government at the time: "risk to Spain of possible retaliation by

\footnotetext{
${ }^{68}$ Viñas, "Negotiating the U.S.-Spanish Agreements," 22.

${ }^{69}$ In fact, despite the 1970 agreement described below, Americans in 1973 used the bases in Spain to support Israel in the Yom Kippur War, violating the strict neutrality declared by Spain. Ibid, 23.

${ }^{70}$ James Cortada, ed. Spain in the Twentieth-Century World: Essays on Spanish Diplomacy, 1898-1978 (Westport: Greenwood Press, 1980), 248-249.
} 
United States enemies, no security guarantee, large United States visibility of bases and personnel not for defense of Spain but for NATO, risk of danger from United States operations and excercises...possible inhibitions upon Spanish independence in foreign policy, and affront to Spanish pride in that Spain rents its territory without the status of equal partnership."71

In order to put a limit on American use of the bases, the Spanish negotiators requested the wartime activation clause to be made public and the new base agreement to have "a clause establishing the necessity for prior agreement for the war use of the armed forces of the United States stationed in Spain." 72 The Spanish argued that the secrecy of the activation clause "could seriously damage" the two countries" relations "in the eyes of public opinion" and that "the automatic use of the bases cannot continue." 73 In addition to diplomatic, strategic, and domestic political concerns, the Spanish might have raised the issue as a negotiation tactic: the Spanish Minister of Foreign Affairs had earlier expressed their willingness to collaborate in security affairs with the United States "the same, lesser, or even more...depending on the degree of security and protection that the United States would be in a position to offer." ${ }^{, 74}$ The United States acceded to the Spanish request. The following explanation was given in a State Department document, which was presumably prepared as talking points to members of the Senate Committee on Foreign Relations: "Since we did not intend to give Spain a security commitment and made this clear in the negotiations, they insisted on more control over the bases. Therefore, the 1953 Secret Annex was dropped from the new agreement." ${ }^{\text {,75 }}$ Thus, Article 34 of

\footnotetext{
71 "Memorandum for Mr. Henry A. Kissinger Chairman, NSC Review Group" (Department of State, January 12, 1970), p.7. Retrieved from Digital National Security Archive.

${ }^{72}$ See documents in "April 1970" folder in box 11 of the following: Department of State, Entry 5600, Bureau of European Affairs, 1963-76, RG 59, Stack 150, Row 73, National Archives at College Park. The quotation is from the pp.3-4 of "NOTE" dated April 12, 1970.

73 "NOTE" undated, p.3 in "April 1970" folder. See the previous footnote.

74 "NOTE" dated April 12, 1970, p.4.

75 "TALKING POINTS" in "May 1970" folder in box 11 of the following: Department of State, Entry 5600, Bureau of European Affairs, 1963-76, RG 59, Stack 150, Row 73, National Archives at College Park.
} 
the 1970 agreement states that "the time and manner of" American use of the bases "will be the subject of urgent consultations between the two Governments, and will be resolved by mutual agreement in light of the situation created."

\section{Treaty of Friendship and Cooperation between the United States and Spain}

In the previous periods of the alliance, the United States did not demand safeguards against entrapment by Spain, simply because the superpower was not obligated to defend Spain in the first place. This situation changed when the United States signed a new agreement with post-Franco Spain in January 1976. This time, the two parties reached a formal treaty with the approval of the U.S. Senate, and the United States, for the first time in the alliance, gave Spain a security guarantee "in case of an attack against Spain or the United States in the context of a general attack against the West" (Supplementary Agreement on Bilateral Military Coordination, Article II). With this new development, the United States imposed a limit on the alliance by defining "the geographic area of common interest," which clearly excluded contingencies in North Africa. Americans had repeatedly told the Spaniards that they would not help Spain with its problems in its African colonies, and the words had been proven true. ${ }^{76}$ With a formal defense commitment made, however, Americans re-emphasized their attitude toward Spain's problems in North Africa. Diplomatic records on the negotiation for the 1976 treaty are still largely unavailable, but probable causes of the new geographic restriction are the formalization of the American commitment and the instability of the North African region, where in November 1975, Morocco staged a mass demonstration, crossing into Spanish Sahara in order to "reunite" the territory. ${ }^{77}$

The U.S.-Spain alliance began without conditions on alliance obligations, because neither

\footnotetext{
${ }^{76}$ Viñas, "Negotiating the U.S.-Spanish Agreements," 14-15.

${ }^{77}$ In addition to Spain and Morocco, an indigenous independence movement and Mauritania also claimed the territory (now Western Sahara).
} 
party feared entrapment. The allies added safeguard clauses to the alliance agreement as they discovered potential situations for entrapment and as they increased commitment to each other. Even though the risk of entrapment was a relatively minor issue in the alliance, both the stronger and the weaker ally still made efforts to reduce the risk. The case also illustrates that the risk of entrapment is part of the overall alliance management and that states balance the fear of entrapment with other concerns. Spain balanced the fear of entrapment not only with the fear of abandonment but also with the military and economic aid from the United States.

Table 1 summarizes the findings of the case studies. Because the United States had more bargaining power than its allies in all the cases, its alliance obligations were more conditional when it feared entrapment. When the allies of the United States had the fear of entrapment and when their bargaining power was relatively strong, they succeeded in restricting their alliance obligations and the United States' freedom of action. When there was little fear of entrapment or when the side with the fear of entrapment had weak bargaining power, alliance obligations were less conditional. 
Table 1. The Fear of Entrapment, Bargaining Power, and Conditions on Alliance Obligations

\begin{tabular}{|c|c|c|c|}
\hline & $\begin{array}{l}\text { The side with } \\
\text { the fear of } \\
\text { entrapment }\end{array}$ & $\begin{array}{l}\text { Bargaining power } \\
\text { of lesser allies }\end{array}$ & $\begin{array}{c}\text { Conditions on alliance } \\
\text { obligations }\end{array}$ \\
\hline $\begin{array}{l}\text { US-South Korea, } \\
1953\end{array}$ & United States & Weak & Limited U.S. obligations. \\
\hline US-Japan, 1951 & Japan & Weak & $\begin{array}{l}\text { Did NOT limit Japanese } \\
\text { obligations (U.S. freedom). }\end{array}$ \\
\hline US-Japan, 1960 & Japan & Strong & $\begin{array}{l}\text { Limited Japanese } \\
\text { obligations (U.S. freedom). }\end{array}$ \\
\hline US-Spain, 1963 & Neither & Weak & No condition. \\
\hline US-Spain, 1970 & Spain & Strong & $\begin{array}{l}\text { Limited Spanish } \\
\text { obligations (U.S. freedom). }\end{array}$ \\
\hline US-Spain, 1976 & United States & Strong & Limited U.S. obligations. \\
\hline
\end{tabular}

\section{Beyond My Cases}

Readers might wonder how generalizable my argument is, given that all my cases are U.S. alliances formed during the Cold War. In addition to the uniqueness of the period, the vast capability of the United States and its legalistic foreign policy might make my cases appear to be outliers. A separate paper is necessary to address the issue of generalizability, but my analysis of the ATOP dataset suggests a wide applicability of this paper's argument. For instance, with simple descriptive statistics, we can see that conditions of alliance agreements vary according to the type of alliance obligations, a major factor that affects the risk of entrapment (see Table 2). 
Table 2. Types of Commitments and Conditions (member level) ${ }^{78}$

\begin{tabular}{|c|c|c|c|c|}
\hline Conditions summary & $\begin{array}{c}\text { Defense } \\
52.0 \% \\
(472 / 908)\end{array}$ & $\begin{array}{c}\text { Offense } \\
87.7 \% \\
(200 / 228)\end{array}$ & $\begin{array}{c}\text { Neutrality } \\
84.0 \% \\
(204 / 243)\end{array}$ & $\begin{array}{c}\text { Consultation } \\
39.6 \% \\
(446 / 1126)\end{array}$ \\
\hline Specific adversary & $27.5 \%$ & $75.9 \%$ & $18.1 \%$ & $6.7 \%$ \\
\hline Specific location & $26.1 \%$ & $25.9 \%$ & $6.2 \%$ & $24.8 \%$ \\
\hline Particular conflict & $10.5 \%$ & $42.5 \%$ & $1.6 \%$ & $3.6 \%$ \\
\hline Number of adversaries & $1.5 \%$ & $2.2 \%$ & $2.1 \%$ & $\mathrm{~N} / \mathrm{A}$ \\
\hline $\begin{array}{l}\text { Demands being met by an } \\
\text { ally or an adversary }\end{array}$ & $0.8 \%$ & $12.7 \%$ & $0.4 \%$ & $\mathrm{~N} / \mathrm{A}$ \\
\hline No provocation & $9.0 \%$ & $\mathrm{~N} / \mathrm{A}$ & $6.2 \%$ & $\mathrm{~N} / \mathrm{A}$ \\
\hline Ally being attacked & $\mathrm{N} / \mathrm{A}$ & $\mathrm{N} / \mathrm{A}$ & $70.0 \%$ & $\mathrm{~N} / \mathrm{A}$ \\
\hline
\end{tabular}

Table 2 demonstrates that offense $(87.7 \%)$ and neutrality $(84.0 \%)$ obligations, which are associated with higher risks of entrapment, are much more likely to be conditional than defense $(52.0 \%)$ and consultation obligations $(39.6 \%) .{ }^{79}$ Even defensive alliances entail a risk of entrapment by a provocative action of a state, but offensive alliances are far more susceptible to risky or offensive actions on the part of one of the alliance partners. Because the risk of entrapment is smaller when a state is only obligated to consult its ally, consultation pacts are less conditional. Neutrality pacts are tricky because they impose a risk of undesirable noninvolvement. By definition, neutrality pacts are agreements against military involvement in an ally's conflict, but such agreements are necessary exactly because the state may have an interest in getting involved in the ally's conflict. Since neutrality of a state can be exploited by other states with offensive purposes, unconditional neutrality pacts leave room for opportunistic behavior. Therefore, neutrality pacts create a perverse fear of entrapment into non-action and are

\footnotetext{
${ }^{78}$ Because members of an alliance can have different obligations and conditions, it is better to use member-level data than alliance-level data. The second row shows the percentage of each obligation being conditional in any aspect. A consultation obligation can also be conditional upon an ally requesting consultation.

${ }^{79}$ In the ATOP dataset, an alliance can contain more than one type of obligations.
} 
fairly conditional. For instance, the Nazi-Soviet Pact of 1939 contained a neutrality clause conditional on being attacked by a third party.

Table 2 further shows which obligation is conditional in what aspect, and we can see how alliance members select specific conditions. The most conditional of all are offense obligations regarding the adversaries $(75.9 \%)$. Naturally, a state does not want to commit itself to offense obligations without specifying the target. Offense obligations are also likely to be conditional upon a particular ongoing conflict $(42.5 \%)$, because states are reluctant to accept such strong commitments as offense unless that is necessary to win a conflict, and the end of the conflict usually diminishes the necessity of offense obligations. The condition of no provocation by an ally is not as common as we might expect, but this probably reflects the difficulty of judging what constitutes "provocation" and the subtleties of diplomatic language. After World War I, non-provocation clauses "came into disrepute" because they "made it easier for a country to evade its obligation on the ground that its ally had caused the war." ${ }^{, 80}$ Thus, $70 \%$ of neutrality obligations are conditional upon the ally being attacked while only $6.2 \%$ of them are conditional upon the ally not provoking the adversary.

\section{CONCLUSION}

This paper pointed out the conceptual problems of "entrapment" in alliance literature and differentiated entanglement and entrapment, which is a subset of the former. States carefully design alliances to reduce the risk of entrapment while accepting the risk of entanglement. Case studies of the U.S. alliances with South Korea, Japan, and Spain demonstrate that allies keep redesigning alliances to deal with the risk of entrapment in accordance with their bargaining power.

\footnotetext{
${ }^{80}$ Arnold Wolfers, "Alliances," in International Encyclopedia of the Social Sciences 1, ed. David Sills, (New York: Macmillan-Free Press, 1968), 269.
} 
Having explained how to observe entrapment analytically, which has never been done in alliance literature before, this paper empirically demonstrates that states do fear entrapment. Rarity of entrapment does not mean that states do not fear it, and entrapment rarely happens exactly because of the fear and states' efforts to cope with it. The case studies show that states pay attention to details of alliance agreements, and it may well be that these details had significant impact on many states' decisions about military entanglement.

One may wonder, then, why states do not always safeguard against every undesirable contingency in alliance agreements. Unexpected things happen, but even predictable contingencies are often not mentioned in alliance contracts. As James Morrow points out, leaving some ambiguity gives allies a benefit in deterrence and discourages them from taking advantage of explicit commitments. ${ }^{81}$ We need to keep in mind, however, that the distribution of the benefit among allies is not equal, and states bargain hard for a better position within their alliances. States with less fear of abandonment can negotiate hard, while states with more fear of abandonment have to make demands carefully. Because states need to balance the risk of entrapment with the risk of abandonment, they sometimes have to accept the risk of entrapment. ${ }^{82}$ As in the case of Franco's Spain, it is also conceivable that states accept some risk of entrapment for side payments made by their allies. ${ }^{83}$

Like deterrence, the effect of the safeguard clauses against entrapment is hard to observe, because what we observe is a non-event, but there are several reasons to believe that they are quite effective. If safeguard clauses had no real effects, states would not exert so much effort in designing and negotiating their contents. If the conditions on alliance obligations did not matter,

\footnotetext{
${ }^{81}$ Morrow, "Why Write Them Down?": 73.

${ }^{82}$ Snyder, "Dilemma in Alliance" and Alliance Politics.

${ }^{83}$ This is a situation different from voluntary military involvement for side payments, because the states are accepting only the possibility of entrapment in the future and do not desire the military involvement.
} 
there should not be such a significant difference between the early and more recent findings on alliance reliability. ${ }^{84}$ Furthermore, when safeguard clauses apply and a state still chooses to get involved (i.e. when a state involves itself in a conflict of its ally without being obligated to do so), there is a good chance that the state has a motivation not related to the alliance — and thus the state is not really entrapped or entangled.

I conclude with two related policy implications. First, as long as their contents are carefully designed, military alliances do not have to entail a high risk of entrapment. George Washington considered unwise the extension of alliances without shared interests, but the origin of the U.S.-ROK alliance suggests that it can be equally unwise to refrain from an alliance when shared interests are at stake. Since states can adjust the risk of entrapment through the designs of alliances, and since alliances give states some control on their allies' policy, extending alliance commitments may actually make the states less likely to get involved in military conflicts, even without the deterrence effects of military alliances. Given that states also engage in military conflicts against their allies less and less — an effect of alliances that has proven surprisingly weak in the past ${ }^{85}$-military alliances have a potential of becoming strong institutions of international security management.

Second, and finally, the distribution of capabilities in the current international system

\footnotetext{
${ }^{84}$ See the introduction of this paper.

${ }^{85}$ When we examine how alliances end, approximately $10.1 \%(52 / 513)$ of alliance membership terminations under multipolarity is attributable to intra-alliance war, whereas only $3.5 \%(13 / 373)$ during the Cold War and none (0/165) between 1990 and 2003 ended in intra-alliance war. Russia and Georgia, both members of the Commonwealth of Independent States, fought South Ossetia War in 2008. One study shows that alliances reduce conflict among members by providing information about their relative capabilities, and this effect is particularly strong when allies are near power parity. See David Bearce, Kristen Flanagan and Katharine Floros, "Alliances, Internal Information, and Military Conflict Among Member-States," International Organization, 60, no.3 (Summer 2006): 595-625. For an explanation of how certain provisions of alliance agreements promote peace among allies, see Andrew Long, Timothy Nordstrom and Kyeonghi Baek, "Allying for Peace: Treaty Obligations and Conflict between Allies," Journal of Politics 69, no.4, (November 2007): 1103-1117.
} 
may be a blessing to the United States but a curse to others. ${ }^{86}$ Fear of entrapment is not a good rationale for a more restrained U.S. grand strategy, because, under unipolarity, the United States not only has advantages over potential and actual adversaries but also over potential and actual allies. With its bargaining advantages, the United States may well benefit from modifying the contents of its alliance commitments, but withdrawing from alliance commitments altogether would be a misguided policy, because these commitments alone are not likely to drag the United States into a costly war. Additionally, these commitments enhance U.S. influence on the allies and deterrence against potential enemies. Meanwhile, the United States has more power to entrap its allies, and other states have more reasons to accept entrapment in order to avoid abandonment by the sole super-ally. It remains to be seen how American leaders can use their advantage in constructive ways and how leaders of other countries will come up with acceptable solutions to their problems.

\footnotetext{
${ }^{86}$ On implications of unipolarity on international relations, see, for example, the special issue of World Politics, vol.61, no.1 (January 2009), "International Relations Theory and the Consequences of Unipolarity" eds. G. John Ikenberry, Michael Mastanduno, and William C. Wohlforth.
} 